\title{
Long-term Organic Production Systems in Northern Highbush Blueberry: Placing Weed Mat over Existing Organic Mulches and Changing to Nitrogen-only Fertilizer Sources Increased Yield
}

\author{
Amanda J. Davis and Bernadine C. Strik \\ Department of Horticulture, Oregon State University, 4017 ALS, \\ Corvallis, OR 97331 \\ Additional index words. compost, nutrient management, sawdust, soybean fertilizer, \\ Vaccinium corymbosum
}

\begin{abstract}
In long-lived organic blueberry production systems, nutrient imbalances caused by some fertilization and mulching practices can reduce plant growth and yield. The ability to balance nutrient levels and thus improve productivity over time was evaluated in a mature planting of 'Duke' and 'Liberty' that had been used to study different mulching practices [sawdust (9-cm deep), yard-debris compost (4-cm) topped with sawdust $(5-\mathrm{cm})$, and weed mat] and various rates and sources of $\mathrm{N}$ fertilizer (feather meal or fish solubles, each applied initially at "low" or "high" rates of 29 and $57 \mathrm{~kg} \cdot \mathrm{ha}^{-1} \mathrm{~N}$ in $2007-08$ and then increased incrementally as the planting matured to 73 and $140 \mathrm{~kg} \cdot \mathrm{ha}^{-1}$ $N$ in 2013-16). In Winter 2016-17, existing weed mat was removed and replaced where it was present, and new weed mat was installed on top of any existing organic mulches, thus changing the mulch treatments to weed mat (over bare soil), weed mat over sawdust, and weed mat over compost + sawdust from 2017 to 2020 . A hydrolyzed soyprotein-based fertilizer containing essentially only $N$ was applied at a moderate rate (106 $\mathbf{k g} \cdot \mathrm{ha}^{-1} \mathrm{~N}$ ) relative to prior treatments. Plants grown on flat and raised beds were evaluated separately. From 2016 to 2020, yield of 'Duke' and 'Liberty' increased by an average of $19 \%$ and $56 \%$, respectively, on flat beds and $8 \%$ and $42 \%$, respectively, on raised beds. On flat or raised beds, plants that had weed mat placed over the existing sawdust or compost + sawdust mulch had a greater increase in yield (averaging $41 \%$ ) than those with weed mat alone (over bare soil; averaging $12 \%$ ). Soil under weed mat alone continued to have the lowest organic matter content (averaging 3\%) throughout the study. Prior fertilization source and rate had no impact on the increase in yield of 'Duke', whereas 'Liberty' plants previously fertilized with feather meal had a larger increase in yield through 2020 than those fertilized with fish solubles. Fertilizing with an intermediate rate of $\mathbf{N}$ from 2017 to 2020 increased yield regardless of whether plants received the low or high $N$ rate from 2007 to 2016, confirming our previous conclusion that the low rate provided sufficient $\mathrm{N}$. Soil $\mathrm{K}$ and leaf $\% \mathrm{~K}$ declined after discontinuing fertilization with fish solubles and use of yard-debris compost, likely a factor in yield improvement. However, there were still negative correlations between yield and leaf $\% \mathrm{~K}$ in multiple years. This study illustrated that changing mulch and fertility practices in established organic blueberry to mitigate prior applications of high $\mathrm{K}$ can improve plant performance, nutrient imbalances, and yield within a relatively short period of time.
\end{abstract}

The northwestern United States is the largest growing region for blueberries

Received for publication 7 Apr. 2021. Accepted for publication 12 May 2021

Published online 18 June 2021

We appreciate the funding support provided by the Oregon Blueberry Commission and the Northwest Center for Small Fruits Research, as well as inkind support from Westbridge Agricultural Products, BirdGard LLC, and Bird Control Group.

B.C.S. is the corresponding author. E-mail: bernadine.strik@oregonstate.edu.

This is an open access article distributed under the CC BY-NC-ND license (https://creativecommons. org/licenses/by-nc-nd/4.0/)
(Vaccinium corymbosum L.) in the country, accounting for $48 \%$ of the total production in 2018 (North American Highbush Blueberry Council, unpublished). The amount of certified organic production continues to increase and nearly one-quarter of blueberry growers in Oregon have certified organic land (DeVetter et al., 2015; Fernandez-Salvador et al., 2017; Strik, 2014, 2016). Today, more than $20 \%$ of the total blueberry area in the region is certified organic, representing more than $60 \%$ of the total U.S. organic production of blueberries (North American Highbush Blueberry Council, unpublished). In the early 2000 s, only $\approx 2 \%$ of the total blueberry area in the region was organic, and growers had many questions on how to successfully produce the crop organically (Strik, 2016). The most common production system used in the region at the time was planting on raised beds or flat ground, mulching the in-row area with douglas fir [Pseudotsuga menziesii (Mirb.) Franco var. menziesii] sawdust, hand-pulling or hoeing weeds, and fertilizing with fish solubles as a source of $\mathrm{N}$ at rates of $100-140$ $\mathrm{kg} \cdot \mathrm{ha}^{-1}$ for mature plants.

Our long-term, certified organic research trial was initiated in 2006 to study management practices, including planting method (raised or flat beds), fertilizer source and rate (feather meal and fish solubles at "low" and "high" rates of 73 and $140 \mathrm{~kg} \cdot \mathrm{ha}^{-1} \mathrm{~N}$ at maturity), and mulch type (sawdust, yard-debris compost topped with sawdust, and a porous, black, polyethylene groundcover called weed mat) in two cultivars (Duke and Liberty). Results from this trial showed improved root growth and yield during establishment with planting on raised beds compared with flat ground (Larco et al., 2013a) and 22\% higher cumulative yield in 'Liberty' over the 10-year study (Strik et al., 2017a). Planting on raised beds has since become standard industry practice. Fertilization with fish solubles, particularly at the higher rate, reduced yield as much as 35\% in 'Duke' (Strik et al., 2017a). Fertilization with fish solubles and adding yard-debris compost to the mulch resulted in high soil and leaf $\mathrm{K}$ concentration that was negatively correlated with yield in 'Duke' and contributed to nutrient imbalances such as low leaf $\mathrm{Ca}$ and $\mathrm{Mg}$ (Strik et al., 2019). Lower rates of fertilizer N (73 vs $140 \mathrm{~kg} \cdot \mathrm{ha}^{-1}$ ) increased yield overall (Strik et al., 2017a). Based on the results of this study, growers reduced the total rate of $\mathrm{N}$ applied and avoided using only fish solubles as a fertilizer source, supplementing with other products (Fernandez-Salvador et al., 2017; Strik, 2016). Although composts can be used in organic production systems as a source of nutrients and organic matter, high $\mathrm{pH}$ and high levels of $\mathrm{K}$ and other nutrients (Sullivan et al., 2014) are concerning for long-term management. Also, adding a yard-debris compost to a sawdust mulching program increased weed management costs (Strik and Vance, 2017), had no benefit for yield or fruit quality (Strik et al., 2017a), and increased soil and leaf K to levels that might reduce yield (Strik et al., 2019). In situations in which soil K levels are high, stopping use of mulch or fertilizer sources containing $\mathrm{K}$ may improve soil and plant nutrient status and yield over time.

Using weed mat as a mulch has resulted in similar or improved yield compared with organic mulches such as sawdust (Krewer et al., 2009; Larco et al., 2013a; Strik et al., 2017a, 2017b), and has been a more cost-effective mulching strategy (Julian et al., 2012; Magee and Spiers, 1996; Sciarappa et al., 2008; Strik and Vance, 2017). However, weed mat mulch over bare soil has increased soil temperature and irrigation requirement (Larco, 2010; Neilsen et al., 2003; Strik et al., 2017a, 2020a; Williamson et al., 2006) and reduced soil organic matter (Strik et al., 2019). In a separate long-term study of organic northern 
highbush blueberry, adding weed mat on top of a layer of sawdust showed great promise in mitigating the negative effects noted for weed mat alone (Strik et al., 2017b). Subsequent research in establishing 'Duke' blueberries showed that a mulch combination of black weed mat over sawdust reduced soil temperature, improved plant biomass and nutrient uptake, and increased yield in the second growing season as compared with plants grown with black weed mat alone (Strik et al., 2020a, 2020b; Strik and Davis, 2021). Placing weed mat over existing organic mulches in mature blueberry plantings would likely reduce weed management costs, but the impact on soil and plant nutrients and yield has not been defined.

The goal of this study was to determine whether altering mulch and fertilizer practices in an existing long-term trial on certified organic northern highbush blueberry would mitigate nutrient problems observed (Strik et al., 2019). Our objective was to determine the effects of switching to a source of fertilizer containing no $\mathrm{K}$, ceasing the use of yarddebris compost, and placing weed mat mulch over existing organic mulches on soil and plant nutrient status and yield over 4 years. In addition, our goal was to compare changes in plant and soil nutrient status and relationships between nutrient levels and yield to those measured in the previous study (Strik et al., 2017a, 2019).

\section{Materials and Methods}

The study site was a 0.4 -ha block established in Oct. 2006 at Oregon State University's North Willamette Research and Extension Center (Aurora, OR; lat. $45^{\circ} 16^{\prime} 47^{\prime \prime} \mathrm{N}$, long. $\left.122^{\circ} 45^{\prime} 23^{\prime \prime} \mathrm{W}\right)$. The planting was certified organic from the first cropping year (2008) through 2020 by a U.S. Department of Agriculture-accredited certifier (Oregon Tilth, Corvallis, OR). The soil is mapped as a Willamette silt loam (a fine-silty, mixed, superactive mesic Pachic Ultic Argixeroll). Details on the establishment of the planting are provided elsewhere (Larco et al., 2013a, 2013b). Plant spacing was $0.8 \mathrm{~m} \times$ $3.0 \mathrm{~m}$ (4385 plants/ha). A permanent grass cover crop was grown in the row aisles and mowed during the growing season, as required. The planting was pruned each winter per standard commercial practice (Strik, 2020). To help control spotted wing drosophila [Drosophila suzukii (Matsumura)], the planting was sprayed with either a spinosad (metabolites of Saccharopolyspora spinosa) insecticide (Entrust SC; Dow Agro Science, Indianapolis, IN) or a pyrethrin (PyGanic EC 1.4; Valent, Walnut Creek, CA). The products were applied once every 7 to $14 \mathrm{~d}$ from when 'Liberty' fruit first turned blue through the end of harvest. Weeds present in the row or crown area of the plant were pulled by hand, and a string trimmer was used to manage grass along the edge of the weed mat mulch. A scare alarm (Bird Gard LLC, Sisters, OR) and laser (AgriLaser, Bird Control Group, Delft, Netherlands; 2016, 2019-20) were used to reduce depredation from birds. No other pests were observed or identified in the planting through the course of the study. Other management practices during the long-term study were described by Larco et al. (2013a, 2013b) and Strik et al. (2017a, 2017b).

From 2006 to 2016, there were 48 treatment combinations arranged in a split-splitplot design with five replicates. The main plots were planting method [raised beds ( $\approx 0.3-\mathrm{m}$ high) or flat ground], the subplots were fertilizer rate and source ("low" or "high" target rate of 28 and $56 \mathrm{~kg} \cdot \mathrm{ha}^{-1} \mathrm{~N}$, respectively, in 2007-09, and then increased incrementally as the planting matured to 73 and $140 \mathrm{~kg} \cdot \mathrm{ha}^{-1} \mathrm{~N}$, respectively, 2013-16; feather meal or fish solubles), and the subsubplots were mulch treatment ['compost + sawdust' (a 4-cm-deep layer of municipal yard-debris compost covered by 5-cm-deep douglas fir sawdust), 9-cm-deep layer of sawdust, or weed mat (black, woven polyethylene groundcover as described later in this article)] and cultivar (early-season 'Duke' and midseason 'Liberty'). Sub-subplots were 4.6-m long with six plants in each sub-subplot at establishment. Details on fertilizer sources, nutrient content, application method, and timing are explained by Strik et al. (2019). The mulches are further described and characterized by Strik et al. (2017a, 2019) and Sullivan et al. (2015). The present study was conducted from 2017 through 2020 (years 11-14), as described in the following section.

In winter before the 2017 growing season, the existing weed mat mulch in the relevant treatment was removed. The irrigation drip tube in the entire planting was then replaced as it had reached the end of its functional lifespan. New polyethylene drip tubing $\left(2 \mathrm{~L} \cdot \mathrm{h}^{-1}\right.$ pressure-compensating, inline emitters every $0.46 \mathrm{~m}$; Netafim, Fresno, CA) was installed with two lines, one on each side of the plants in the row. Black weed mat (water flow rate of $6.8 \mathrm{~L} \cdot \mathrm{m}^{-2}$ per $\mathrm{h} ; 0.11 \mathrm{~kg} \cdot \mathrm{m}^{-2}$; TenCate Protective Fabrics; OBC Northwest Inc., Canby, OR) was then applied to the in-row area of the entire planting, as this was the best mulch treatment for economical weed control (Strik and Vance, 2017) and had increased yield of 'Liberty' compared with the sawdust and compost + sawdust mulches (Strik et al., 2017a). Existing sawdust and compost + sawdust mulches (typically $<3-\mathrm{cm}$ deep on raised beds and 3 - to $6-\mathrm{cm}$ deep on flat ground) or bare soil, where old weed mat had been removed, were covered by the new weed mat. Therefore, the mulch treatments evaluated in this trial were weed mat over bare soil (since 2006) and weed mat over either compost + sawdust or sawdust (since 2017).

The planting was irrigated three to seven times per week, generally from mid to late May through September each year with irrigation adjusted based on air temperature and stage of plant development. From 2017 to 2020, plants were fertigated with a target $\mathrm{N}$ rate of $106 \mathrm{~kg} \cdot \mathrm{ha}^{-1} \mathrm{~N}$, a rate that was intermediate between the low and high $\mathrm{N}$ rates used in the prior experiment (Strik et al., 2017a). Liquid Biolink Vegan N (5.5-0-0) and dry soluble Biolink (14-0-0) (Westbridge Agricultural
Products, Vista, CA) were used in 2017 and 2018-20, respectively; both are a hydrolyzed soy-protein-based fertilizer source. These products were chosen based on their low levels of nutrients other than $\mathrm{N}$, as high levels of $\mathrm{K}$ found in fish solubles were negatively correlated with yield in this planting from 2008 to 2016 (Strik et al., 2019). A sample of fertilizer was submitted each year to a commercial testing laboratory for analysis of macro- and micronutrients (Brookside Laboratories, New Bremen, $\mathrm{OH})$. The fertilizer treatments evaluated in this trial were thus low $\left(73 \mathrm{~kg} \cdot \mathrm{ha}^{-1} \mathrm{~N}\right)$ and high $\left(140 \mathrm{~kg} \cdot \mathrm{ha}^{-1} \mathrm{~N}\right)$ rates of either feather meal or fish solubles (from 2013 to 2016), which were all changed to $106 \mathrm{~kg} \cdot \mathrm{ha}^{-1} \mathrm{~N}$ of soy-protein-based product fertigated from 2017 to 2020. Fertilizer was split into seven applications that occurred biweekly from midApril through early July each year.

Foliar B was applied when leaf tissue sampling indicated a deficiency $\left(2.2 \mathrm{~kg} \cdot \mathrm{ha}^{-1} \mathrm{~B}\right.$ on 11 Oct. 2018 and $1.3 \mathrm{~kg} \cdot \mathrm{ha}^{-1} \mathrm{~B}$ on $12 \mathrm{Apr}$. 2019; Solubor, U.S. Borax, Chicago, IL). Soil sampling in autumn 2018 showed that $\mathrm{pH}$ had risen above the recommended range for blueberry (4.5-5.5; Hart et al., 2006) in all treatments and, therefore, granular elemental sulfur was applied on top of the weed mat on 11 Mar. 2019 (288 $\mathrm{kg} \cdot \mathrm{ha}^{-1} \mathrm{~S}$, Tigur 90CR; Tigur-Sul Products LLC, Atmore, AL).

Data collection. Plant tissue (most-recent fully expanded leaves in late July to early August) and soil (late October to early November) samples were collected each year from three replicates per treatment. Soil was sampled between plants to a depth of $0.2 \mathrm{~m}$ at the center of the row using a 2.4-cm-diameter chromeplated steel soil probe (Soil Sampler Model Hoffer; JBK Manufacturing, Dayton, $\mathrm{OH}$ ). Mulch was removed from the soil surface before taking the samples and replaced afterward. Ripe fruit were sub-sampled from the first harvest of each cultivar in 2018 and 2020 for nutrient analysis. Soil and tissue samples were analyzed for macro- and micronutrients, organic matter, and $\mathrm{pH}$ by a commercial testing laboratory (Brookside Laboratories, New Bremen, $\mathrm{OH})$, as described further by Strik et al. (2019).

Ripe fruit were harvested by hand or using an over-the-row machine harvester (Littau Harvester, Stayton, OR) approximately every 7 to $10 \mathrm{~d}$ from each experimental unit (plot). 'Duke' was harvested two times per year, between 23 June and 11 July, and 'Liberty' was harvested three times per year, between 13 July and 17 Aug. The fruit were weighed from each plot and divided by the number of plants per plot to calculate yield per plant. During the course of the study, any presence of the commonly occurring pollen-borne Blueberry shock virus (BlShV) was noted, and the proportion of the plot showing symptoms (necrotic flowers), and thus not producing fruit, was estimated annually. We did not see a high incidence of BlShV that would have a large impact on yield in the planting but did adjust yield to account for any estimated fruit loss from the virus in individual plots as needed. 
Statistical analysis. Data were analyzed using PROC MIXED in SAS software package version 9.4 (SAS Institute, Cary, NC). A separate trial in this plot required the removal of plants from high fertilizer rate treatments in raised beds, so data were analyzed separately for flat and raised beds in this study due to the unbalanced design. Yield and leaf and soil nutrients were analyzed across years, including the final year of the previous study (2016) as a comparator, using a split-split plot design [year as the main effect $(\mathrm{n}=5)$, prior fertilizer rate and source as the subplot $(n=4)$, and combinations of cultivar and mulch as sub-subplots $(n=6)]$. Fruit nutrient concentrations were analyzed separately by year, as those data were only collected in 2018 and 2020. Orthogonal contrasts were used to compare the effect of historical fertilizer source and rate and mulch type on measured variables throughout this study period. Means were separated at the 5\% level using Tukey's honestly significant difference test. Correlation analysis was performed using PROC CORR to determine relationships between leaf nutrients in a particular year and yield in that same year for individual plots in 'Duke' and 'Liberty' ( $\mathrm{n}=72$ for flat beds and $n=36$ for raised beds). A calculation of percent change for yield per plant from 2016 to 2020 was made using data from individual plots measured in both years, rather than from the treatment means.

\section{Results and Discussion}

\section{Soil characteristics}

Soil was sampled from both 'Duke' and 'Liberty'; however, cultivar did not affect soil nutrients, $\mathrm{pH}$, or organic matter (data not shown). Therefore, only data from 'Duke' were reported, as this was the only cultivar used for soil nutrient analysis in our prior study (Strik et al., 2019). Most soil nutrients were affected by year and mulch type for both flat and raised beds, whereas prior fertilizer source and rate had a greater effect in flat beds (Table 1).

$\mathrm{pH}$ and organic matter. Soil $\mathrm{pH}$ was lowest during the final year of the previous study (5.0 and 5.4 for flat and raised beds, respectively) and increased by 0.7 to 1.0 units in 2018 after the existing mulches were topped with weed mat. Less rainwater (which typically has a $\mathrm{pH}$ of $\approx 5.5$; Hart et al., 2013) was able to permeate the weed mat than the previous organic mulches, which likely reduced cation leaching and raised the soil $\mathrm{pH}$. The application of granular sulfur dropped the $\mathrm{pH}$ in subsequent years. Weed mat over sawdust mulch had the lowest $\mathrm{pH}$ in both flat and raised beds (5.7 and 5.8, respectively, averaged over 2017-20), just as in the previous study (Strik et al., 2019). Sawdust and other wood chip mulches have been found to lower soil $\mathrm{pH}$ in blueberry grown in various soils and climatic conditions worldwide (Cox, 2009; Karp et al., 2006). In flat beds, soil under weed mat alone had a significantly higher $\mathrm{pH}$ (6.0) than for weed mat over compost + sawdust (5.8), whereas weed mat alone and weed mat over compost + sawdust had similar soil $\mathrm{pH}$ in raised beds (averaged 6.0 ). The compost applied in the prior study had a high $\mathrm{pH}$ (7.4), which resulted in higher soil $\mathrm{pH}$ under that mulch for the 2007-16 period and seemed to have a persistent effect lasting years after the last application (2013 for flat beds and 2015 for raised beds). In flat beds, contrasts showed that prior (2007-16) fertilizer source and rate continued to affect soil $\mathrm{pH} ; \mathrm{pH}$ was lower with prior use of feather meal (5.7, averaged over 2017-20) than with fish solubles (5.9), and when fertilizer had been applied at the high rate, the $\mathrm{pH}$ was lower (5.7) than with the low rate (5.9). Although the high $\mathrm{N}$ rate also resulted in lower soil $\mathrm{pH}$ in the previous study due to nitrification of excess $\mathrm{N}$ fertilizer, it was surprising that long-term effects were found after the fertilizer rate was shifted to a moderate level for all plants. Previous fertilization practices (at the low rate of $\mathrm{N}$ ) had no effect on soil $\mathrm{pH}$ in raised beds in this study.

Soil organic matter was affected mainly by mulch but did not change significantly within each mulch type from 2016 to 2020 , despite the addition of weed mat on top of the organic mulches. When weed mat was applied over top of the existing organic mulches, a thicker layer of sawdust or compost + sawdust remained on flat beds as compared with raised beds, where it more readily wore off the sides of the beds (A. Davis, personal observation). We continued to see the same significant pattern as was found at the end of the prior study (Strik et al., 2019), where soil organic matter was lowest for weed mat alone, likely due to higher soil temperatures under weed mat compared with organic mulches (Strik et al., 2017a), which is thought to encourage faster breakdown of organic matter due to higher microbial activity (Conant et al., 2011; Davidson et al., 2006). When weed mat was placed over sawdust during establishment of blueberry plants, soil temperature was higher than with sawdust alone but lower than weed mat over bare soil (Strik et al., 2020a). In this study, compared with weed mat over bare soil, soil organic matter was moderate for weed mat over sawdust and highest for weed mat over compost + sawdust $(2.9 \%, 4.1 \%$, and $5.0 \%$, respectively, for raised beds and $3.1 \%, 4.3 \%$, and $5.2 \%$, respectively, for flat beds in 2020). Although the compost used had a lower concentration of organic matter than sawdust when the mulches were applied, the greater bulk density and stability of the compost resulted in higher contribution of organic matter to the soil beneath the compost + sawdust mulch (Sullivan et al., 2015). Although soil bulk density was not measured, it required less effort to insert the soil probe in the weed mat over the organic mulch treatments as compared with weed mat over bare soil (A. Davis, personal observation).

Table 1. Results of analysis of variance for the impact of year (2016-20; $\mathrm{n}=5$ ), prior fertilizer source (applied 2007-16, feather meal or fish solubles), and rate (low: $73 \mathrm{~kg} \cdot \mathrm{ha}^{-1} \mathrm{~N}$ and high: $140 \mathrm{~kg} \cdot \mathrm{ha}^{-1} \mathrm{~N}$ in $2016 ; \mathrm{n}=4$ ), and mulch (weed mat over compost + sawdust, weed mat over sawdust, weed mat alone; $\mathrm{n}=3$ ) on soil $\mathrm{pH}$, organic matter, and nutrients in 'Duke' northern highbush blueberry grown on flat or raised beds in a certified organic planting at Oregon State University's North Willamette Research and Extension Center in Aurora, OR.

\begin{tabular}{|c|c|c|c|c|c|c|c|c|c|c|c|c|c|c|}
\hline \multirow[b]{2}{*}{ Significance $^{z}$} & \multirow[b]{2}{*}{ Soil pH } & \multirow{2}{*}{$\begin{array}{c}\text { Soil } \\
\text { organic } \\
\text { matter }(\%)\end{array}$} & \multicolumn{12}{|c|}{ Soil nutrient concn (ppm) } \\
\hline & & & $\mathrm{NO}_{3}$ & $\mathrm{NH}_{4}$ & $\mathrm{P}$ & $\mathrm{K}$ & $\mathrm{Ca}$ & $\mathrm{Mg}$ & $\mathrm{B}$ & $\mathrm{Fe}$ & $\mathrm{Mn}$ & $\mathrm{Cu}$ & $\mathrm{Zn}$ & $\mathrm{Al}$ \\
\hline \multicolumn{15}{|l|}{ Flat beds } \\
\hline Year (yr) & $<0.0001$ & NS & NS & 0.0046 & 0.0155 & $<0.0001$ & 0.0009 & $<0.0001$ & 0.0350 & 0.0010 & 0.0009 & NS & $<0.0001$ & $<0.0001$ \\
\hline Fertilizer (fert) & $<0.0001$ & NS & 0.0012 & NS & $<0.0001$ & $<0.0001$ & NS & 0.0024 & NS & NS & 0.0020 & NS & NS & 0.0027 \\
\hline $\mathrm{Yr} \times$ Fert & NS & NS & 0.0419 & NS & NS & NS & NS & NS & NS & NS & 0.0500 & NS & NS & NS \\
\hline Mulch & $<0.0001$ & $<0.0001$ & $<0.0001$ & NS & NS & $<0.0001$ & $<0.0001$ & $<0.0001$ & 0.0151 & 0.0001 & NS & NS & $<0.0001$ & $<0.0001$ \\
\hline Yr $\times$ Mulch & NS & NS & NS & NS & NS & 0.0311 & 0.0444 & 0.0026 & NS & NS & NS & NS & NS & 0.0187 \\
\hline Fert $\times$ Mulch & NS & 0.0319 & NS & NS & NS & 0.0041 & NS & 0.0155 & NS & NS & NS & NS & NS & NS \\
\hline Yr $\times$ Fert $\times$ Mulch & NS & NS & NS & NS & NS & NS & NS & 0.0470 & NS & NS & NS & NS & NS & NS \\
\hline \multicolumn{15}{|l|}{ Raised beds } \\
\hline Year (yr) & 0.0005 & NS & 0.0443 & 0.0002 & 0.0088 & 0.0009 & NS & 0.0010 & 0.0064 & 0.0049 & 0.0077 & NS & $<0.0001$ & 0.0009 \\
\hline Fertilizer (fert) & NS & NS & NS & NS & 0.0003 & 0.0040 & NS & NS & NS & NS & NS & NS & 0.0014 & NS \\
\hline Yr $\times$ Fert & NS & NS & NS & NS & NS & NS & NS & NS & NS & NS & NS & NS & NS & NS \\
\hline Mulch & 0.0093 & $<0.0001$ & NS & 0.0387 & NS & $<0.0001$ & $<0.0001$ & 0.0021 & 0.0174 & 0.0026 & NS & $<0.0001$ & $<0.0001$ & $<0.0001$ \\
\hline Yr $\times$ Mulch & NS & NS & 0.0229 & NS & NS & NS & NS & NS & NS & NS & NS & NS & NS & NS \\
\hline Fert $\times$ Mulch & NS & NS & NS & NS & NS & NS & NS & NS & NS & 0.0313 & NS & NS & 0.0232 & NS \\
\hline Yr $\times$ Fert $\times$ Mulch & NS & NS & NS & NS & NS & NS & NS & NS & NS & NS & NS & NS & NS & NS \\
\hline
\end{tabular}

${ }^{\mathrm{z}}$ Results from full analysis of variance. Nonsignificant (Ns) or actual $P$ value provided when significant $(P<0.05)$. 
Soil N. On average (2017-20), soil nitrate $\left(\mathrm{NO}_{3}\right)$ was highest with weed mat over compost + sawdust (4.8 ppm) compared with the other mulches (averaged $1.8 \mathrm{ppm}$ ) in flat beds, whereas there was no main effect of mulch in raised beds (averaged $2.3 \mathrm{ppm}$ ). This contrasts with our previous findings, where soil $\mathrm{NO}_{3}$ was lower under compost + sawdust (without weed mat on top) than weed mat alone (Strik et al., 2019). Soil temperatures likely increased when weed mat was placed on top of the compost + sawdust mulch, which probably increased nitrification from both applied fertilizer and residual $\mathrm{N}$ in the compost and, with less nutrient leaching from rainfall, led to higher $\mathrm{NO}_{3}$ levels during this study. In raised beds, soil $\mathrm{NO}_{3}$ was higher in 2019 than in other years, and although there was a year $\times$ mulch interaction, there was no consistent trend between years (data not shown). Soil $\mathrm{NO}_{3}$ was higher on flat beds where the high rate of fertilizer had been previously applied (3.7 ppm, averaged over 2017-20) compared with the low rate (1.9 ppm), even though all plants were fertilized with the same moderate $\mathrm{N}$ rate $\left(106 \mathrm{~kg} \cdot \mathrm{ha}^{-1}\right.$ N) since 2017; this indicates that some residual $\mathrm{N}$ remained in the soil, but by 2020 , there were no differences between fertilizer rates (averaged $2.2 \mathrm{ppm}$ ). Fertilizer source did not affect soil $\mathrm{NO}_{3}$ in flat beds, and neither source nor rate affected $\mathrm{NO}_{3}$ in raised beds or ammonium $\left(\mathrm{NH}_{4}\right)$ in either bed type. In both flat and raised beds, soil $\mathrm{NH}_{4}$ was higher in 2018 than in the other years and, averaged over the study period, was lower in weed mat alone (2.1 ppm and $2.0 \mathrm{ppm}$ in flat and raised beds, respectively) than in the weed mat over sawdust and weed mat over compost + sawdust mulch treatments $(3.0 \mathrm{ppm}$ and $2.4 \mathrm{ppm}$ in flat and raised beds). In our previous study, soil $\mathrm{NH}_{4}$ was highest under weed mat alone (4.9 ppm averaged over 2008-16) compared with the organic mulches (3.1 ppm) (Strik et al., 2019).

Soil P. Soil $\mathrm{P}$ was lower in 2017-20 (averaged $169 \mathrm{ppm}$ and $173 \mathrm{ppm}$ for flat and raised beds, respectively) than in 2016 (195 ppm and $199 \mathrm{ppm}$ for flat and raised beds). Although both previous fertilizer sources contained $\mathrm{P}$, particularly fish solubles, the soy-protein fertilizer used in this study contained very low $\mathrm{P}$ ( $\leq$ $0.01 \%$ ). However, even these reduced levels of soil $\mathrm{P}$ were above recommended sufficiency levels ( $>100$ ppm considered excessive; Horneck et al., 2011). In flat beds, prior fertilizer source (2007-16) did not affect soil P, but the high rate of either fertilizer continued to have higher soil $\mathrm{P}$ (179 ppm, averaged over 2017-20) than the low rate (147 ppm). In raised beds, in which only the low rates could be compared, plots formerly fertilized with fish solubles had higher soil P over 2017-20 (181 ppm) than those previously fertilized with feather meal (151 ppm).

Soil cations. At the end of the prior study in 2016, soil K was highest and considered excessive under the compost + sawdust mulch due to high levels of $\mathrm{K}$ in the compost (Strik et al., 2019). Since that year, soil K declined significantly for all mulches from
2017 to 2020 in both flat and raised beds. However, soil $\mathrm{K}$ remained highest in weed mat over compost + sawdust due to the residual $\mathrm{K}$ contributed by the compost and was lowest with weed mat over sawdust throughout this study (weed mat alone was intermediate) (Fig. 1A). There was a year $\times$ mulch interaction in flat beds because of the large drop in soil K from 2016 to 2017 when weed mat was placed over compost + sawdust as compared with the other mulches. Strik et al. (2019) reported that soil K was higher with weed mat alone than with sawdust because of less infiltration by rainfall and less leaching, and with the relatively low mobility of $\mathrm{K}$ in soil and no additional $\mathrm{K}$ fertilization, this effect remained in place for 4 years after weed mat was placed over the sawdust mulch. In plots that were previously fertilized with fish solubles, soil K continued to remain higher in 3 of 4 years in flat beds (154 ppm in 2020, averaged over prior rate) than where feather meal had been used (125 $\mathrm{ppm}$ ), whereas effects of prior fertilizer use were no longer present in raised beds from 2017 to 2020 (averaged 147 ppm K in 2020). Strik et al. (2019) found that soil K was greater in flat beds than raised beds, particularly in the final 2 years of the study (2015-16), which we suspected was due to better drainage in raised beds. This is likely the same reason why fertilizer effects were more persistent in flat beds than raised beds.

During this study, soil $\mathrm{Ca}$ increased from 2016 levels in flat beds and was lowest with weed mat over sawdust for the first 2 years, just as it was in 2016 (Strik et al., 2019), but by 2019 , soil $\mathrm{Ca}$ in that mulch was similar to weed mat alone (Fig. 1B). Although the soyprotein fertilizer used in this study had low $\mathrm{P}$ and $\mathrm{K}$ concentrations, it contained more $\mathrm{Ca}$ (an average of $6.4 \mathrm{~kg} \cdot \mathrm{ha}^{-1}$ per year) than the fish solubles that had been used in 2007-16 and equivalent amounts of $\mathrm{Ca}$ to some of the feather meal products used previously (Strik et al., 2019). Weed mat over compost + sawdust had the highest soil $\mathrm{Ca}$ in 2019-20, possibly because the compost contained relatively high levels of $\mathrm{Ca}$ (Strik et al., 2019) that continued to be released into the soil, especially with higher soil temperatures found under weed mat. In raised beds, soil $\mathrm{Ca}$ was only affected by mulch, with weed mat over sawdust having the lowest soil $\mathrm{Ca}$ (989 ppm, averaged over 2017-20) compared with weed mat alone and weed mat over compost + sawdust (1234 ppm). Historical fertilizer use did not affect soil $\mathrm{Ca}$ in either bed type.

Soil $\mathrm{Mg}$ followed similar patterns as soil $\mathrm{Ca}$, although the increase was consistent for both flat and raised beds (flat beds shown in Fig. 1C, raised beds not shown). In this case, the fertilizer contributed negligible amounts of $\mathrm{Mg}$ (less than the detectable limits in 2018-20) compared with the fertilizers used before this study (Strik et al., 2019). Similar to soil $\mathrm{Ca}$, soil $\mathrm{Mg}$ was lower under sawdust mulch and highest under weed mat alone in 2016 (Strik et al., 2019). From 2017 to 2020 in raised beds, weed mat over sawdust had lower soil Mg (294 ppm, on average) than weed mat alone (322 ppm), whereas weed mat over compost + sawdust was intermediate (318 ppm). In flat beds, there was a year $\times$ mulch interaction, as the difference in soil $\mathrm{Mg}$ between mulches from 2016 to 2018 declined to the point at which they were quite similar in the final 2 years of the study (Fig. 1C).

Soil micronutrients. All soil micronutrients except $\mathrm{Cu}$ were affected by year (Table 1), although patterns of increase or decrease were often not consistent across years or between flat and raised beds (data not shown). Mulch affected $\mathrm{B}, \mathrm{Fe}, \mathrm{Cu}$ (in raised beds only), and $\mathrm{Zn}$, with weed mat over compost + sawdust generally having the highest levels and either weed mat over sawdust or weed mat alone having the lowest (data not shown). No soil micronutrients were considered deficient, except B (ranged from 0.3 to $0.5 \mathrm{ppm} ;<0.5 \mathrm{ppm}$ considered low; Horneck et al., 2011), which is typically low in soils in this region and was compensated for with foliar applications of B when leaf tissue testing indicated it was necessary. Soil $\mathrm{Fe}, \mathrm{Cu}, \mathrm{Mn}, \mathrm{Zn}$, and $\mathrm{Al}$ ranged from 309 to $318 \mathrm{ppm}, 0.91$ to $0.93 \mathrm{ppm}, 28.9$ to 30.4 ppm, 2.6 to $2.8 \mathrm{ppm}$, and 1166 to $1177 \mathrm{ppm}$, respectively, from 2017 to 2020 over both flat and raised beds.

\section{Leaf nutrients}

The concentration of many nutrients in the leaves was affected by mulch, prior fertilizer use, and the interactions of those treatments in flat beds (including fertilizer source and rate), whereas these treatments had less long-term effect in raised beds (only fertilizer source included) (Table 2). As expected, both year and cultivar had a significant effect on the leaf concentration of most nutrients (Strik and Vance, 2015; Strik et al., 2019). Therefore, we will focus on the most important impacts of fertilizer and mulch treatments over the course of the study and describe interactions with cultivar when present.

Leaf $N$. Leaf $\mathrm{N}$ concentration increased during the study for all treatments, despite applying a rate of $\mathrm{N}$ that was lower (106 $\mathrm{kg} \cdot \mathrm{ha}^{-1} \mathrm{~N}$ ) than the previously used high rate $\left(140 \mathrm{~kg} \cdot \mathrm{ha}^{-1} \mathrm{~N}\right)$. Plants were considered deficient for leaf $\mathrm{N}$ in 2016, although they appeared to have typical growth and produced a good yield (Strik et al., 2017a), but were near the top of the sufficiency range by 2020 (Fig. 2A). In flat beds, there was a year $\times$ fertilizer interaction because leaf $\mathrm{N}$ was significantly higher with the high rate of $\mathrm{N}$ and with fish solubles in 2016 than for the low rate of $\mathrm{N}$ or feather meal, but no differences between treatments were found once the fertilization was the same from 2017 to 2020 (Fig. 2A). Both flat and raised beds showed a year $\times$ mulch interaction but with slightly different patterns. In raised beds, the differences in leaf $\mathrm{N}$ due to mulch at the end of the former study ( $1.54 \%$ for weed mat compared with $1.43 \%$ averaged over organic mulches in 2016) disappeared by 2018 with no differences thereafter (averaged 1.92\% in 2020). However, in flat beds, weed mat alone 

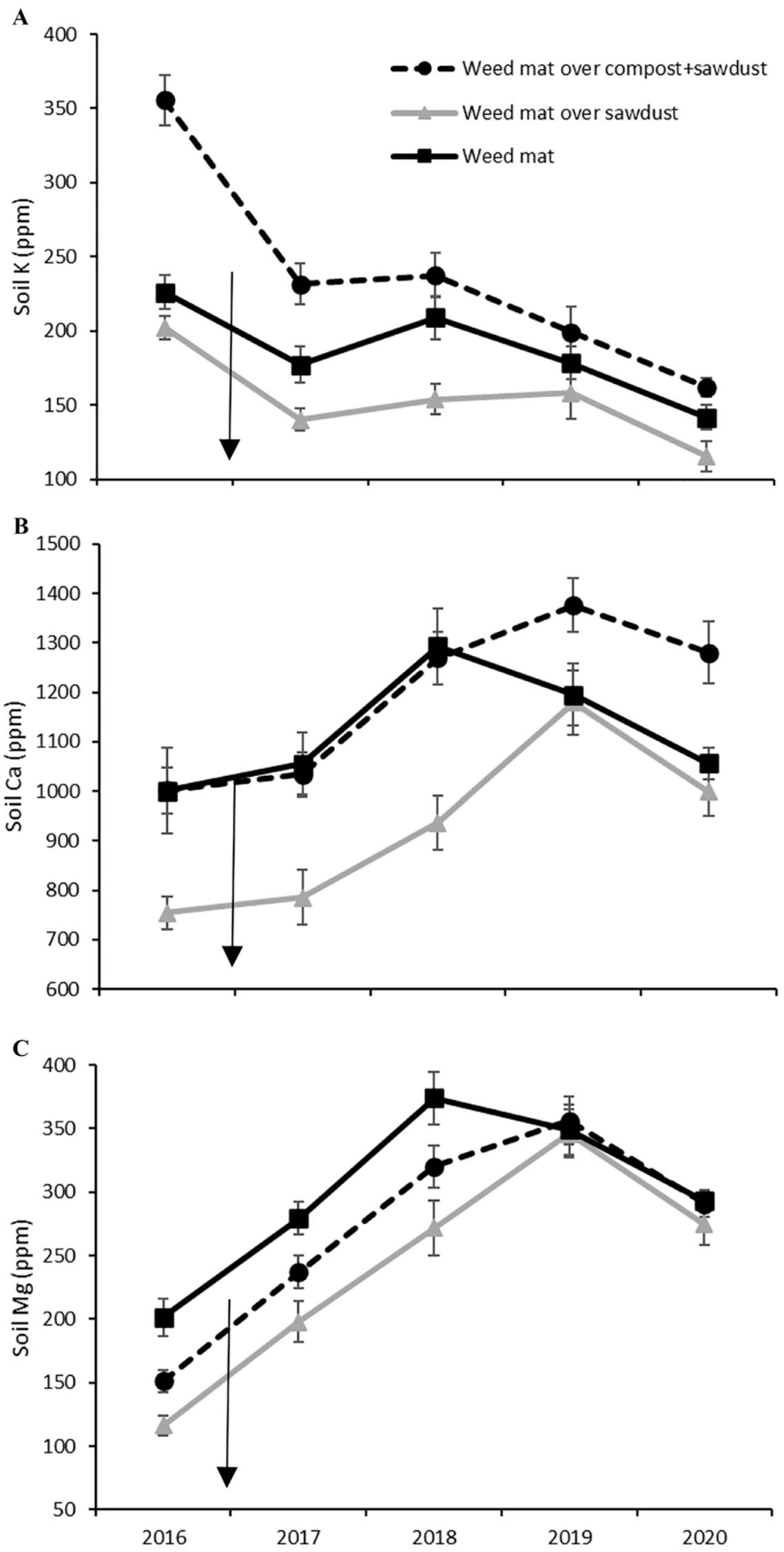

Fig. 1. Effect of mulch on soil (A) K, (B) Ca, and (C) Mg in 'Duke' northern highbush blueberry plants grown on flat beds in a certified organic planting at Oregon State University's North Willamette Research and Extension Center. Means are averaged over prior fertilizer source (applied 2007-16, feather meal or fish solubles) and rate (low: $73 \mathrm{~kg} \cdot \mathrm{ha}^{-1} \mathrm{~N}$ and high: $140 \mathrm{~kg} \cdot \mathrm{ha}^{-1} \mathrm{~N}$ in 2016) treatments. Error bars represent $\pm 1 \mathrm{sE}$. Arrows indicate when weed mat was either replaced or added on top of existing organic mulches and fertilizer source and rate were changed to a soy-protein-based fertilizer at a rate of $106 \mathrm{~kg} \cdot \mathrm{ha}^{-1} \mathrm{~N}$. 
Table 2. Results of analysis of variance for the impact of year $(2016-20 ; n=5$ ), prior fertilizer source (applied 2007-16, feather meal or fish solubles), and rate (low: $73 \mathrm{~kg} \cdot \mathrm{ha}^{-1} \mathrm{~N}$ and high: $140 \mathrm{~kg} \cdot \mathrm{ha}^{-1} \mathrm{~N}$ in 2016; $\mathrm{n}=4$ ), mulch (weed mat over compost + sawdust, weed mat over sawdust, weed mat alone; $\mathrm{n}=3$ ), and cultivar (Duke and Liberty, $\mathrm{n}=2$ ) on leaf nutrient concentration in northern highbush blueberry grown on flat or raised beds in a certified organic planting at Oregon State University's North Willamette Research and Extension Center in Aurora, OR.

\begin{tabular}{|c|c|c|c|c|c|c|c|c|c|c|c|c|}
\hline \multirow[b]{2}{*}{ Significance $^{z}$} & \multicolumn{6}{|c|}{ Leaf macronutrient concn $(\%)$} & \multicolumn{6}{|c|}{ Leaf micronutrient concn (ppm) } \\
\hline & $\mathrm{N}$ & $\mathrm{P}$ & $\mathrm{K}$ & $\mathrm{Ca}$ & $\mathrm{Mg}$ & $\mathrm{S}$ & $\mathrm{B}$ & $\mathrm{Fe}$ & $\mathrm{Mn}$ & $\mathrm{Cu}$ & $\mathrm{Zn}$ & $\mathrm{Al}$ \\
\hline \multicolumn{13}{|l|}{ Flat beds } \\
\hline Year (yr) & $<0.0001$ & $<0.0001$ & 0.0007 & 0.0100 & 0.0002 & $<0.0001$ & 0.0005 & 0.0004 & NS & $<0.0001$ & NS & $<0.0001$ \\
\hline Fertilizer (Fert) & NS & NS & 0.0376 & 0.0003 & 0.0002 & NS & 0.0099 & NS & 0.0055 & NS & NS & NS \\
\hline Yr $\times$ Fert & 0.0466 & NS & NS & 0.0333 & NS & 0.0368 & NS & NS & NS & NS & NS & NS \\
\hline Mulch & 0.004 & NS & NS & $<0.0001$ & 0.0115 & NS & $<0.0001$ & NS & $<0.0001$ & 0.0003 & NS & $<0.0001$ \\
\hline Yr $\times$ Mulch & $<0.0001$ & NS & NS & NS & NS & NS & NS & NS & 0.0004 & NS & NS & NS \\
\hline Fert $\times$ Mulch & NS & 0.0030 & NS & 0.0313 & $<0.0001$ & 0.0024 & 0.0026 & 0.0260 & NS & NS & NS & 0.0383 \\
\hline Yr $\times$ Fert $\times$ Mulch & NS & NS & NS & NS & NS & NS & NS & NS & NS & NS & NS & NS \\
\hline $\mathrm{cv}$ & $<0.0001$ & NS & $<0.0001$ & $<0.0001$ & $<0.0001$ & 0.0139 & $<0.0001$ & $<0.0001$ & $<0.0001$ & $<0.0001$ & $<0.0001$ & 0.0002 \\
\hline $\mathrm{Yr} \times \mathrm{cv}$ & $<0.0001$ & $<0.0001$ & 0.0005 & $<0.0001$ & $<0.0001$ & $<0.0001$ & $<0.0001$ & NS & $<0.0001$ & $<0.0001$ & NS & NS \\
\hline Fert $\times$ cv & NS & NS & NS & NS & 0.0445 & NS & 0.0220 & NS & 0.0196 & NS & NS & NS \\
\hline Yr $\times$ Fert $\times$ cv & NS & NS & NS & NS & NS & NS & NS & NS & NS & NS & NS & NS \\
\hline Mulch $\times$ cv. & NS & 0.0216 & 0.0458 & NS & NS & 0.0221 & NS & NS & NS & 0.022 & NS & NS \\
\hline Year $\times$ Mulch $\times$ cv & NS & NS & NS & NS & NS & NS & NS & NS & NS & NS & NS & NS \\
\hline Fert $\times$ Mulch $\times$ cv & NS & NS & NS & NS & NS & NS & NS & NS & 0.0319 & NS & NS & NS \\
\hline Yr $\times$ Fert $\times$ Mulch $\times$ cv & NS & NS & NS & NS & NS & NS & NS & NS & NS & NS & NS & NS \\
\hline \multicolumn{13}{|l|}{ Raised beds } \\
\hline yr & $<0.0001$ & $<0.0001$ & 0.0016 & NS & 0.0070 & 0.0013 & 0.0061 & 0.0031 & NS & 0.0002 & NS & 0.0018 \\
\hline Fert & NS & NS & NS & 0.0008 & NS & NS & 0.0013 & NS & 0.0351 & NS & NS & NS \\
\hline Yr $\times$ Fert & NS & NS & NS & NS & NS & NS & NS & NS & NS & NS & NS & NS \\
\hline Mulch & NS & NS & NS & NS & 0.0302 & 0.0001 & 0.0005 & NS & $<0.0001$ & NS & NS & 0.0261 \\
\hline Yr $\times$ Mulch & 0.0001 & NS & NS & NS & NS & NS & 0.0010 & NS & NS & NS & NS & NS \\
\hline Fert $\times$ Mulch & NS & NS & NS & NS & NS & NS & NS & NS & NS & NS & NS & NS \\
\hline Yr $\times$ Fert $\times$ Mulch & NS & NS & NS & NS & NS & NS & NS & NS & NS & NS & NS & NS \\
\hline cv. & 0.0003 & NS & $<0.0001$ & 0.0167 & $<0.0001$ & NS & $<0.0001$ & $<0.0001$ & $<0.0001$ & $<0.0001$ & $<0.0001$ & $<0.0001$ \\
\hline Yr $\times c v$ & $<0.0001$ & 0.0293 & 0.0443 & 0.0488 & 0.0007 & $<0.0001$ & 0.0002 & 0.0018 & $<0.0001$ & 0.0002 & NS & 0.0026 \\
\hline Fert $\times \mathrm{cv}$ & NS & NS & NS & NS & NS & NS & 0.0130 & NS & NS & NS & NS & NS \\
\hline Yr $\times$ Fert $\times$ cv & NS & NS & NS & NS & NS & NS & NS & NS & NS & NS & NS & NS \\
\hline Mulch $\times$ cv. & NS & NS & NS & NS & NS & NS & NS & NS & NS & NS & NS & NS \\
\hline Year $\times$ mulch $\times$ cv & NS & NS & NS & NS & NS & NS & NS & NS & NS & NS & NS & NS \\
\hline Fert $\times$ Mulch $\times$ cv & NS & NS & 0.0202 & NS & NS & NS & NS & NS & NS & NS & NS & NS \\
\hline Yr $\times$ Fert $\times$ Mulch $\times$ cv & NS & NS & NS & NS & NS & NS & NS & NS & NS & NS & NS & NS \\
\hline
\end{tabular}

${ }^{\mathrm{z}}$ Results from full analysis of variance. Nonsignificant (NS) or actual $P$ value provided when significant $(P<0.05)$.

went from having the highest leaf $\mathrm{N}$ in 2016 (1.49\% compared with $1.41 \%$ with the organic mulches) to the lowest in 2020 ( $1.83 \%$ compared with $1.89 \%$ and $1.93 \%$ for weed mat over compost + sawdust and weed mat over sawdust, respectively). 'Duke' had similar or lower leaf $\mathrm{N}$ than 'Liberty' from 2017 to 2020 (data not shown) but had higher leaf $\mathrm{N}$ in 2016 and throughout the prior study (Strik et al., 2019). In contrast, 'Liberty' was found to have the highest leaf $\mathrm{N}$ in a study of six cultivars grown conventionally, including 'Duke' (Strik and Vance, 2015).

Leaf $P$. Leaf $\mathrm{P}$ ranged from $0.08 \%$ to $0.11 \%$, depending on year, with no cultivar effect in most years (data not shown). Although leaf concentrations were at or below current sufficiency standards for this region (Hart et al., 2006), soil P was considered excessive, and recent research supports lowering the recommended levels (Davenport and DeVetter, 2019; Strik and Vance, 2015). In raised beds, there were no effects of prior fertilizer treatment or mulch on leaf $\mathrm{P}$ (Table 2 ), but in flat beds, leaf $P$ was higher with weed mat alone in 'Duke' $(0.101 \%)$ than in 'Liberty' $(0.097 \%)$. Also in flat beds, there was a mulch $\times$ fertilizer interaction, but the small differences in leaf $\% \mathrm{P}$ are likely not of biological significance (ranged from $0.099 \%$ to $0.103 \%$ ).
Leaf $K$. Both cultivars followed a similar pattern in leaf $\mathrm{K}$ concentration, with an increase from 2016 to 2017 of $10 \%$ and $12 \%$ for flat and raised beds, respectively, resulting in the highest leaf $\mathrm{K}$ values of the study period in $2017(0.64 \%$ and $0.56 \%$ for 'Duke' and 'Liberty', respectively, on flat beds and $0.69 \%$ and $0.58 \%$ on raised beds). Leaf $\mathrm{K}$ then decreased in 2018, after which changes in levels were relatively minor for the remainder of the study $(0.50 \%$ and $0.46 \%$ for 'Duke' and 'Liberty', respectively, on flat beds and $0.56 \%$ and $0.50 \%$ for 'Duke' and 'Liberty' on raised beds in 2020, averaged across mulch and prior fertilizer treatment). 'Duke' had higher leaf K than 'Liberty' in all years, but a mulch $\times$ cultivar interaction in flat beds showed that leaf $\mathrm{K}$ was higher in 'Duke' with weed mat alone $(0.55 \%$, averaged over 2017-20) than with weed mat over sawdust $(0.52 \%)$, whereas mulch did not affect leaf $\mathrm{K}$ in 'Liberty' (averaged 0.46\%).

Leaf $\mathrm{Ca}$. Leaf $\mathrm{Ca}$ concentration fluctuated from year to year. Averaged over 2017-20, 'Duke' had higher leaf Ca $(0.61 \%$ and $0.58 \%$ in flat and raised beds, respectively) than 'Liberty' $(0.58 \%$ and $0.57 \%$ for flat and raised beds, respectively). In flat beds, contrasts showed that prior use of the low $\mathrm{N}$ rate led to higher leaf $\mathrm{Ca}$ than the high $\mathrm{N}$ rate $(0.61 \%$ and $0.58 \%$, respectively, averaged over 2017-20), and there was a year $\times$ fertilizer interaction due to greater shifts in leaf $\mathrm{Ca}$ with the former low $\mathrm{N}$ rate treatments than for the high rate (Table 2, Fig. 2B). There was a positive correlation $(P<0.05)$ between leaf $\mathrm{Ca}$ and leaf $\mathrm{N}$ for plants on flat beds in 3 of 4 years (data not shown, no correlation in raised beds), whereas we had previously found that leaf $\mathrm{Ca}$ was negatively correlated with leaf $\mathrm{N}$ for both cultivars in several years (Strik et al., 2019). Because there was a trend $(P<0.1)$ for plants previously fertilized with the low rate of $\mathrm{N}$ to have larger increases in leaf $\mathrm{N}$ from 2017 to 2020 (data not shown), it is possible that higher $\mathrm{N}$ uptake also increased $\mathrm{Ca}$ uptake. Plants grown with weed mat over sawdust mulch from 2017 to 2020 had higher leaf $\mathrm{Ca}(0.63 \%)$ than with weed mat over compost + sawdust $(0.60 \%)$ and weed mat alone $(0.58 \%)$, despite soil $\mathrm{Ca}$ being lower with weed mat over sawdust than the other mulches (Fig. 1). This could be because of lower soil $\mathrm{K}$ with weed mat over sawdust and reduced competition for uptake of $\mathrm{Ca}$. In raised beds, where the low rate of feather meal had been applied from 2007 to 2016, leaf Ca was higher than when the low rate of fish solubles was used $(0.60 \%$ and $0.55 \%$, respectively, averaged over 2017-20) due to the higher $\mathrm{Ca}$ content in feather meal (Strik et al., 2019). 

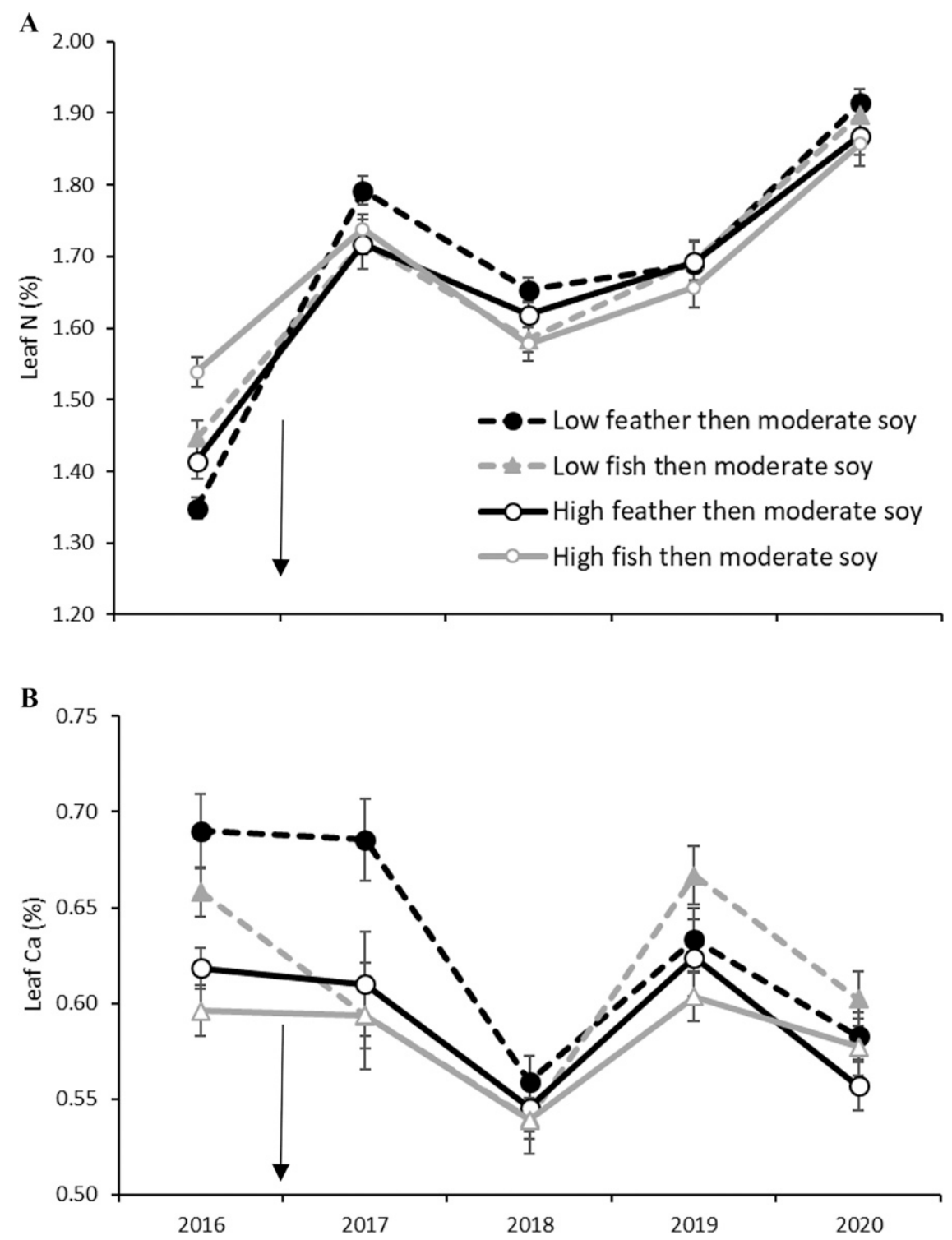

Fig. 2. Effect of prior fertilizer source (applied 2007-16, feather meal or fish solubles) and rate (low: $73 \mathrm{~kg} \cdot \mathrm{ha}^{-1} \mathrm{~N}$ and high: $140 \mathrm{~kg} \cdot \mathrm{ha}^{-1} \mathrm{~N}$ in 2016$)$ on leaf (A) \% $\mathrm{N}$ and (B) $\mathrm{Ca}$ in flat beds, averaged over mulch (weed mat over compost + sawdust, weed mat over sawdust, weed mat alone), and cultivar (Duke and Liberty) from 2016 to 2020 in a certified organic planting of northern highbush blueberry. Error bars represent $\pm 1 \mathrm{SE}$. Arrows indicate when weed mat was either replaced or added on top of existing organic mulches and fertilizer source and rate were changed to a soy-protein-based fertilizer at a rate of $106 \mathrm{~kg} \cdot \mathrm{ha}^{-1} \mathrm{~N}$

Leaf $M g$. 'Duke' had higher leaf Mg concentration than 'Liberty' in all years except 2019, when there was no difference between cultivars (data not shown). Although leaf Mg fluctuated, it was generally similar or slightly lower in $2020(0.17 \%$ and $0.16 \%$ in flat and raised beds, respectively) than in 2016 $(0.19 \%$ and $0.18 \%$ in flat and raised beds), despite higher soil $\mathrm{Mg}$ (Fig. 1C). Leaf $\mathrm{Mg}$ for all treatments was within recommended levels for the duration of the study (Hart et al., 2006). For plants grown on flat beds, leaf $\mathrm{Mg}$ was highest with the combination of weed mat over compost + sawdust and with prior use of the high rate of fish solubles compared with other fertilizers within the same mulch, whereas leaf $\mathrm{Mg}$ was more similar among prior fertilizer treatments for the other mulches. Plants that had been fertilized with the high rate of fish solubles had higher leaf $\mathrm{Mg} \quad(0.18 \%$ and $0.17 \%$ for 'Duke' and
'Liberty', respectively) than with the other fertilizers $(0.16 \%$ in both 'Duke' and 'Liberty'). In raised beds, leaf Mg was lowest with weed mat over sawdust $(0.15 \%)$ and highest in weed mat over bare soil $(0.16 \%)$, averaged over the study period, with no effect of prior fertilization.

Leaf $S$. Leaf $\mathrm{S}$ concentration increased from $2016(0.10 \%)$ to $2020(0.14 \%)$ in both flat and raised beds, and although 'Duke' had higher leaf $S$ than 'Liberty' in 2016, by 2019-20, the opposite was found (data not shown). Although there were some treatment effects on leaf $\mathrm{S}$, differences were generally small ( $\leq 0.01 \%$ ), ranging from $0.12 \%$ to $0.13 \%$ from 2017 to 2020 , and likely not of biological significance.

Leaf micronutrients. There were multiple treatment interactions for leaf B concentration, but in general leaf B was similar at the beginning and end of the study, averaging $44 \mathrm{ppm}$ in flat beds and $42 \mathrm{ppm}$ in raised beds in 2020 (within the recommended range of $30-80$ ppm; Hart et al., 2006). Fertilization before 2017 affected cultivars differently, but differences were small and likely impacted by foliar $\mathrm{B}$ applications (ranged from 47 to $50 \mathrm{ppm}$ in 'Duke' and 41-45 ppm in 'Liberty' in flat beds; 35-40 ppm in 'Liberty' and no difference in 'Duke', averaging 43 ppm, in raised beds). Mulch affected leaf B in both flat beds (ranging from 44 to $49 \mathrm{ppm}$, averaged over 2017-20) and raised beds (39-41 ppm), and weed mat had the highest leaf B in both planting methods compared with other mulches.

Leaf $\mathrm{Fe}$ and $\mathrm{Al}$ concentrations generally declined over the study period and were higher in 'Duke' than in 'Liberty' for both flat and raised beds. When averaged across bed type, year (2017-20), and other treatments, leaf $\mathrm{Fe}$ averaged $187 \mathrm{ppm}$ and $168 \mathrm{ppm}$ and leaf $\mathrm{Al}$ averaged $195 \mathrm{ppm}$ and $177 \mathrm{ppm}$ for 
'Duke' and 'Liberty', respectively. Leaf Zn was also higher in 'Duke' than in 'Liberty' (12 ppm and $10 \mathrm{ppm}$, respectively, in raised beds), but there was no other treatment or year effect. Leaf Mn increased more in 'Liberty' than in 'Duke' between 2016 and 2020, and the difference in leaf $\mathrm{Mn}$ between cultivars grew over the course of the study. Overall, leaf Mn was lower in 'Duke' than 'Liberty' in most years for both flat (113 ppm and 145 ppm, respectively) and raised beds (110 ppm and $133 \mathrm{ppm}$, respectively) when averaged over the 4-year study. Plants previously fertilized with the low rate of fish solubles had lower leaf Mn than other fertilizer treatments in both bed types, although 'Liberty' grown in flat beds had significantly higher leaf Mn when either rate of feather meal (152 ppm) had been applied than when fish solubles were used (138 ppm). In 'Duke', plants that were previously fertilized with the low rate of feather meal (116 ppm) or the high rate of fish solubles (120 ppm) continued to have higher leaf $\mathrm{Mn}$ than with the low rate of fish solubles (105 ppm) when averaged over 2017-20. Plants grown with weed mat over sawdust mulch consistently had higher leaf Mn than the other mulches in both bed types, averaging 143 ppm over the 4-year study in raised beds, compared with 113 ppm with weed mat alone and $107 \mathrm{ppm}$ for weed mat over compost + sawdust (results were similar in flat beds, data not shown). This was most likely due to the lower soil $\mathrm{pH}$ under weed mat over sawdust mulch increasing Mn availability.

Leaf $\mathrm{Cu}$ was generally higher in 'Duke' than in 'Liberty' (3.5 ppm and $2.8 \mathrm{ppm}$, respectively, in raised beds, averaged over 2017-20) and fluctuated from year to year. In raised beds (data not shown) and in 'Liberty' grown on flat beds, leaf $\mathrm{Cu}$ was unaffected by mulch ( $2.8 \mathrm{ppm})$, but in 'Duke' grown on flat beds, weed mat alone led to higher leaf $\mathrm{Cu}(3.6 \mathrm{ppm})$ than the other mulches (averaged $2.8 \mathrm{ppm}$ ). Prior fertilizer use did not affect leaf $\mathrm{Cu}$ in either bed type.

Fruit nutrients. Cultivars differed in the concentration of all nutrients when grown on flat and raised beds in 2018 and 2020, except for $\mathrm{Cu}$ in 2018 (data not shown). On raised beds in 2020, fruit nutrients for 'Duke' averaged $0.70 \% \mathrm{~N}, 0.08 \% \mathrm{P}, 0.52 \% \mathrm{~K}, 0.03 \%$ $\mathrm{Ca}, 0.04 \% \mathrm{Mg}, 0.08 \% \mathrm{~S}, 4.6 \mathrm{ppm} \mathrm{B}, 15 \mathrm{ppm}$ $\mathrm{Fe}, 9.5$ ppm Mn, 7.0 ppm Cu, 7.3 ppm Zn, and $73 \mathrm{ppm} \mathrm{Al}$. 'Liberty' fruit averaged $0.43 \% \mathrm{~N}, 0.06 \% \mathrm{P}, 0.49 \% \mathrm{~K}, 0.04 \% \mathrm{Ca}$, $0.03 \% \mathrm{Mg}, 0.04 \% \mathrm{~S}, 3.6 \mathrm{ppm} \mathrm{B}, 20 \mathrm{ppm} \mathrm{Fe}$, $13 \mathrm{ppm} \mathrm{Mn}, 1.3 \mathrm{ppm} \mathrm{Cu}, 3.9 \mathrm{ppm} \mathrm{Zn}$, and $143 \mathrm{ppm}$ Al. As with many soil and leaf nutrients, fruit nutrients were more affected by prior fertilizer use and mulch when grown on flat than raised beds, but in flat beds, all fertilizer effects occurred in 2018, indicating the impacts of fertilization history were not long lived. In contrast, Fernandez-Salvador (unpublished) found significant differences in fruit $\mathrm{K}, \mathrm{Ca}, \mathrm{S}$, and $\mathrm{Cu}$ concentrations for 'Duke' grown with feather meal as compared with fish solubles on raised beds, whereas fewer differences were found in 'Liberty'. The use of feather meal, which is high in $\mathrm{Ca}$, increased fruit $\mathrm{Ca}$ in that study, which may improve fruit firmness (Lobos et al., 2020).

Fruit $\mathrm{P}$ and $\mathrm{S}$ concentrations tended to be higher overall in 'Duke' than in 'Liberty', and although fertilizer and mulch had some impacts, the differences were small (ranging between $0.070 \%$ and $0.077 \%$ for $\mathrm{P}$ and $0.04 \%$ and $0.05 \%$ for $\mathrm{S}$ ). In contrast, fruit $\mathrm{K}$ and $\mathrm{Ca}$ concentration tended to be lower in 'Duke' than in 'Liberty', despite higher leaf $\mathrm{K}$ and $\mathrm{Ca}$ concentrations in 'Duke'. In 'Liberty', fruit $\mathrm{K}$ was higher with weed mat over compost + sawdust $(0.54 \%)$ than with weed mat alone $(0.53 \%)$, whereas no mulch effects were found in 'Duke'. Although soil $\mathrm{K}$ was also highest when weed mat was placed over compost + sawdust, we found few positive correlations between soil and fruit $\mathrm{K}$ (and none in any other nutrients) in our previous study (Strik et al., 2019). Plants grown with weed mat over sawdust, which resulted in higher leaf $\mathrm{Ca}$ than other mulches, also had the highest fruit $\mathrm{Ca}$ in 'Duke' $(0.031 \%$ compared with $0.027 \%$ for other mulches), whereas this same mulch led to lower fruit $\mathrm{Ca}$

Table 3. Effects of year, prior fertilizer source and rate, mulch, and cultivar on yield of northern highbush blueberry plants grown on flat and raised beds in a certified organic planting at Oregon State University's North Willamette Research and Extension Center in Aurora, OR.

\begin{tabular}{|c|c|c|}
\hline & \multicolumn{2}{|c|}{ Yield (kg/plant) } \\
\hline & Flat beds & Raised beds \\
\hline \multicolumn{3}{|l|}{ Year } \\
\hline 2016 & $3.58 \mathrm{c}^{\mathrm{z}}$ & $4.18 \mathrm{c}$ \\
\hline 2017 & $2.54 \mathrm{~d}$ & $2.92 \mathrm{~d}$ \\
\hline 2018 & $3.77 \mathrm{c}$ & $4.29 \mathrm{c}$ \\
\hline 2019 & $5.27 \mathrm{a}$ & $6.24 \mathrm{a}$ \\
\hline 2020 & $4.69 \mathrm{~b}$ & $5.07 \mathrm{~b}$ \\
\hline \multicolumn{3}{|l|}{ Fertilizer $^{\mathrm{y}}$} \\
\hline Low feather & $4.26 \mathrm{a}$ & 4.54 \\
\hline Low fish & $4.04 \mathrm{a}$ & 4.54 \\
\hline High feather & $4.01 \mathrm{a}$ & $N A^{x}$ \\
\hline High fish & $3.59 \mathrm{~b}$ & NA \\
\hline \multicolumn{3}{|l|}{ Mulch } \\
\hline Weed mat over compost + sawdust & 3.99 a & 4.43 \\
\hline Weed mat over sawdust & $4.16 \mathrm{a}$ & 4.66 \\
\hline Weed mat & $3.77 \mathrm{~b}$ & 4.53 \\
\hline \multicolumn{3}{|l|}{ Cultivar } \\
\hline Duke & $3.31 \mathrm{~b}$ & $3.56 \mathrm{~b}$ \\
\hline Liberty & $4.63 \mathrm{a}$ & $5.51 \mathrm{a}$ \\
\hline \multicolumn{3}{|l|}{ Significance $^{\mathrm{w}}$} \\
\hline Year $(y r)$ & $<0.0001$ & $<0.0001$ \\
\hline Fertilizer (Fert) & 0.0040 & NS \\
\hline Yr $\times$ Fert & NS & NS \\
\hline Mulch & $<0.0001$ & NS \\
\hline $\mathrm{Yr} \times$ Mulch & $<0.0001$ & 0.0004 \\
\hline Fert $\times$ Mulch & 0.0001 & NS \\
\hline Yr $\times$ Fert $\times$ Mulch & NS & NS \\
\hline Cultivar (cv.) & $<0.0001$ & $<0.0001$ \\
\hline $\mathrm{Yr} \times \mathrm{cv}$ & $<0.0001$ & $<0.0001$ \\
\hline Fert $\times$ cv. & NS & $<0.0001$ \\
\hline Yr $\times$ Fert $\times$ cv. & 0.0099 & NS \\
\hline Mulch $\times$ cv & 0.0005 & NS \\
\hline Year $\times$ mulch $\times \mathrm{cv}$ & NS & 0.0421 \\
\hline Fert $\times$ Mulch $\times$ cv & 0.0396 & 0.0267 \\
\hline Yr $\times$ Fert $\times$ Mulch $\times$ cv. & NS & NS \\
\hline
\end{tabular}

${ }^{\mathrm{z}}$ Means followed by the same letter are not significantly different within treatment as determined by analysis of variance using Tukey's honestly significant difference test $(P>0.05)$.

${ }^{\mathrm{y}}$ Fertilizer treatments applied from 2007 to 2016; rate in 2016 was $73 \mathrm{~kg} \cdot \mathrm{ha}^{-1} \mathrm{~N}$ (low) and 140 $\mathrm{kg} \cdot \mathrm{ha}^{-1} \mathrm{~N}$ (high). All plants were fertilized with $106 \mathrm{~kg} \cdot \mathrm{ha}^{-1} \mathrm{~N}$ from 2017 to 2020 as either 5.5-0-0 (2017) or 14-0-0 (2018-20) soy-protein-based fertilizer.

${ }^{\mathrm{x}} \mathrm{NA}$ indicates data not available. Plants from this previous fertilizer regimen were removed before the beginning of this study.

${ }^{\mathrm{w}} P$ values shown when $P<0.05$. Ns indicates nonsignificance. 
on raised beds. In the prior study (Strik et al., 2017a), 'Liberty' had 22\% greater cumulative yield from 2008 to 2016 on raised beds than flat, so the larger increase in yield on flat beds in this study is notable.

In flat beds, cultivars responded differently to previous fertilization, but in general, plants that had received the high rate of fish solubles through 2016 had lower yield from 2018 to 2020 in both cultivars (Fig. 3). In 'Duke', which had lower yield when fish solubles were used in the previous study (Strik et al., 2017a), the percent increase in yield from 2018 to 2020 was similar, regardless of fertilizer source and rate used through 2016. However, although 'Liberty' was not significantly affected by fertilizer source and rate from 2008 to 2016 (Strik et al., 2017a), we found those previously fertilized with feather meal had a significantly $(P<0.05)$ higher increase in yield (70\%) compared with when fish solubles were used $(42 \%)$. Contrasts showed that plants fertilized with the low $\mathrm{N}$ rate had higher yield $(4.3 \mathrm{~kg} /$ plant per year, averaged over 2017-20) than those previously given the high $\mathrm{N}$ rate $(3.9 \mathrm{~kg} / \mathrm{plant}$ per year) when averaged over prior fertilizer source, mulch, and cultivar.

In our previous study, we found that mulching with weed mat alone (compared with compost + sawdust or sawdust alone) resulted in higher yield in 'Liberty', whereas yields were similar among mulches in 'Duke' (Strik et al., 2017a). In this follow-up study, yield declined for 'Liberty' grown with weed mat alone in 2017 and 2018 and increased for plants mulched with weed mat over compost + sawdust and weed mat over sawdust (Fig. 4). From 2016 to 2020, 'Liberty' grown with weed mat over sawdust had a $91 \%$ and $61 \%$ increase in yield on flat and raised beds, respectively, compared with a $23 \%$ and $13 \%$ increase with weed mat alone. The three mulches followed a more similar trend in 'Duke' than in 'Liberty', but yield was higher for the weed mat over sawdust and weed mat over compost + sawdust in some years compared with weed mat alone. In both cultivars grown on flat beds, weed mat over sawdust had the highest yield from 2018 to 2020 compared with weed mat alone (weed mat over compost + sawdust was either intermediate or similar to weed mat over sawdust) (data not shown). Although soil $\mathrm{pH}$ increased and soil organic matter was similar during this study compared with the previous years, weed mat over sawdust resulted in a lower $\mathrm{pH}$ (close to or within the recommended range for blueberry; Hart et al., 2006) and higher soil organic matter than weed mat alone, likely contributing to greater yield potential. Although these impacts on soil characteristics and yield were also found when weed mat was placed over compost + sawdust, the addition of compost to the production system was more expensive initially and led to excessive soil $\mathrm{K}$ and nutrient imbalances in our prior study, some of which continued in the present study (Strik and Vance, 2017; Strik et al., 2019).
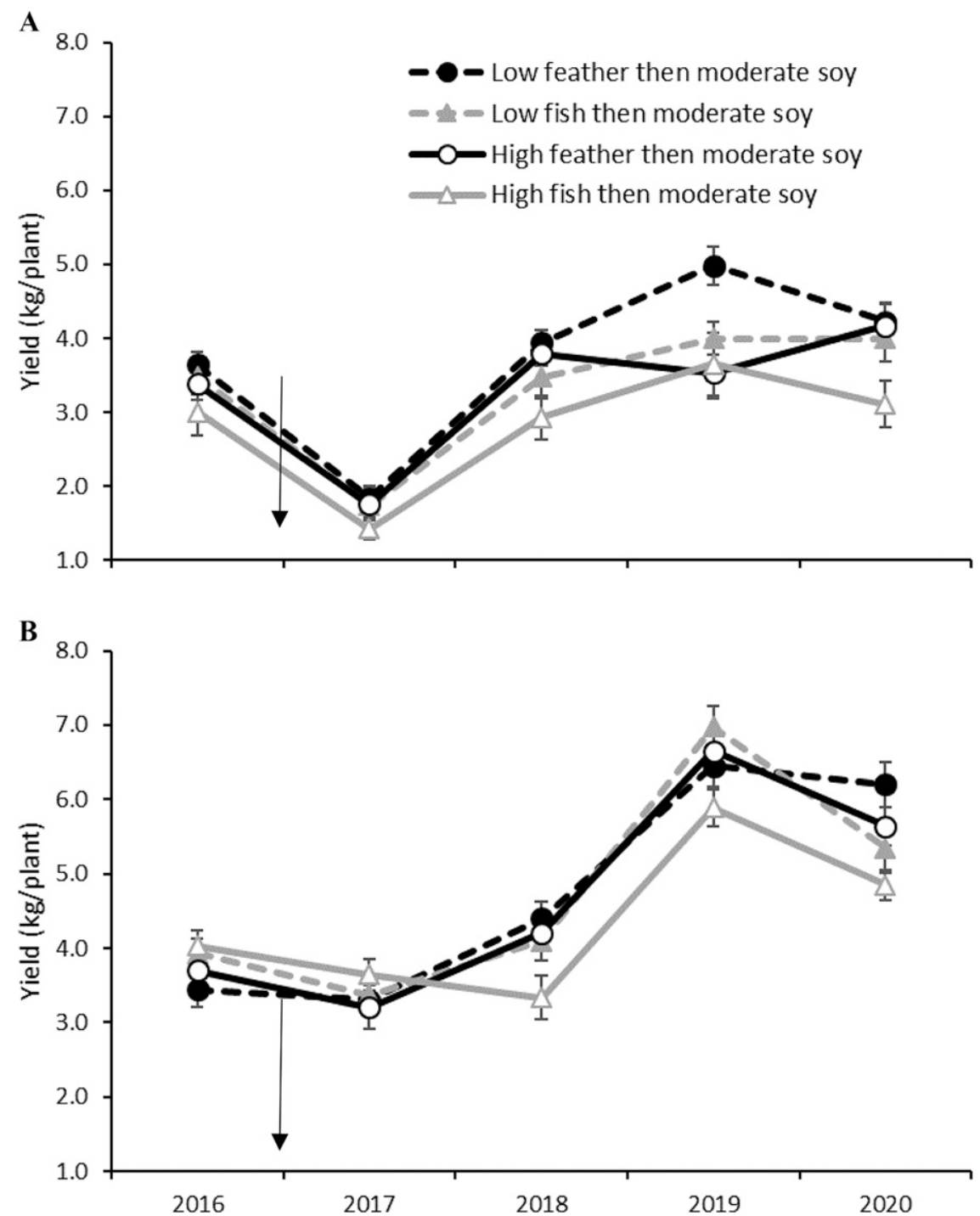

Fig. 3. Effect of previous fertilizer source (applied 2007-16, granular feather meal or fertigated fish solubles) and rate (low: $73 \mathrm{~kg} \cdot \mathrm{ha}^{-1} \mathrm{~N}$; high: $140 \mathrm{~kg} \cdot \mathrm{ha}^{-1}$ $\mathrm{N}$ at maturity) on yield of (A) 'Duke' and (B) 'Liberty' northern highbush blueberry grown on flat beds from 2016 to 2020 . Means are averaged over mulch treatments (weed mat over compost + sawdust, weed mat over sawdust, weed mat alone). Error bars represent \pm 1 SE. Arrows indicate weed mat was either replaced or added on top of existing organic mulches and fertilizer source and rate were changed to a soy-protein-based fertilizer at a rate of $106 \mathrm{~kg} \cdot \mathrm{ha}^{-1} \mathrm{~N}$. 

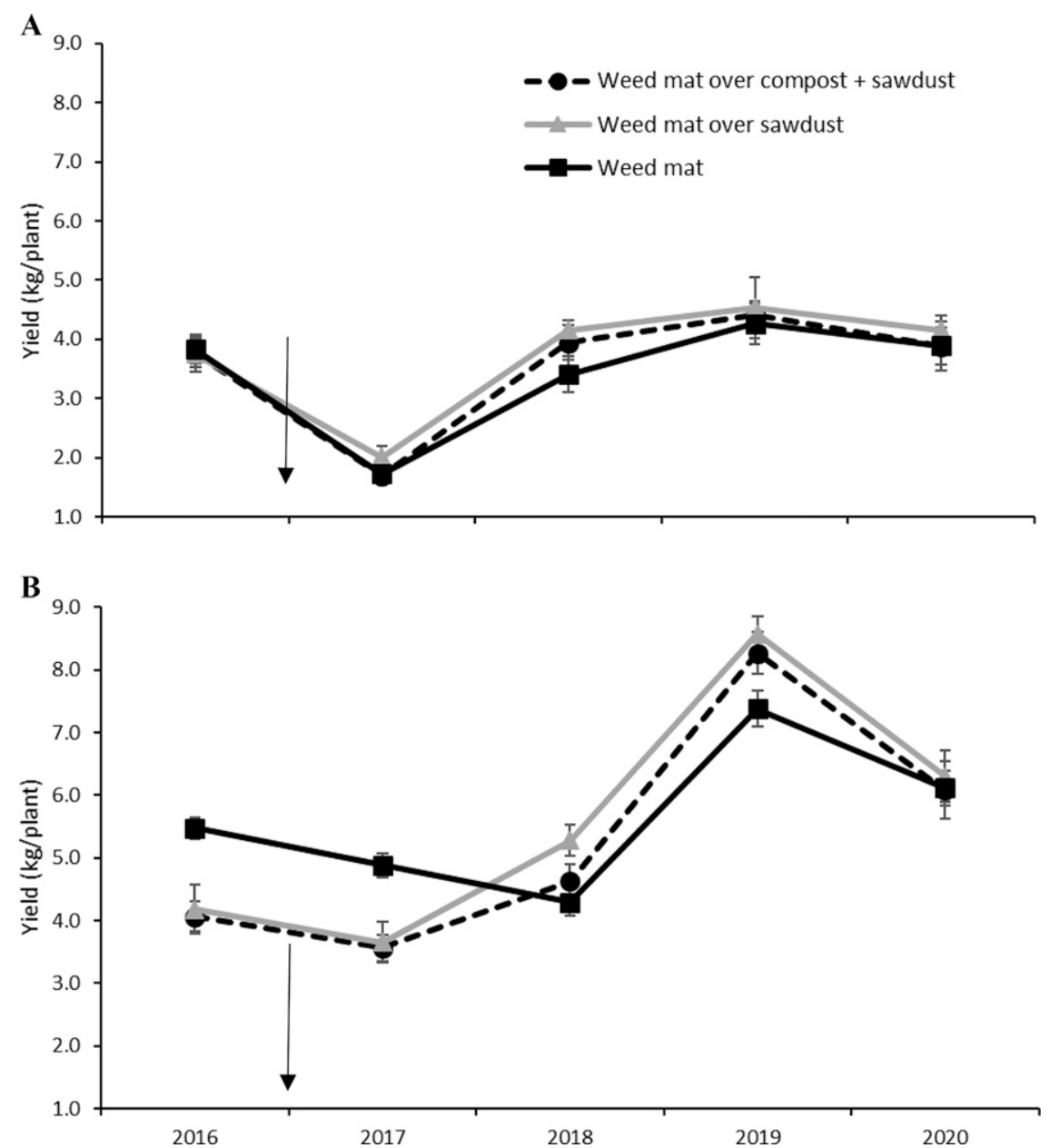

Fig. 4. Effects of mulch (weed mat over compost + sawdust, weed mat over sawdust, weed mat alone) on yield of (A) 'Duke' and (B) 'Liberty' grown on raised beds from 2016 to 2020 , averaged over previous fertilizer source $\left(73 \mathrm{~kg} \cdot \mathrm{ha}^{-1} \mathrm{~N}\right.$ from either granular feather meal or fertigated fish solubles). Error bars represent $\pm 1 \mathrm{SE}$. Arrows indicate when weed mat was either replaced or added on top of existing organic mulches and when fertilizer was changed to a soy-protein-based fertilizer at a rate of $106 \mathrm{~kg} \cdot \mathrm{ha}^{-1} \mathrm{~N}$.

Although we found many interactions among fertilizer and mulch treatments, yield increased for both cultivars after switching to an intermediate rate of $\mathrm{N}$ fertilization in 2017, regardless of whether plants received the low or high $\mathrm{N}$ rate from 2007 to 2016 . Fertilization, particularly with the high rate of fish solubles, had negative long-term effects, especially on flat beds where leaching of mobile nutrients is expected to be less than for raised beds, but those effects diminished gradually over time in our study. The addition of weed mat over sawdust mulch increased yield relative to weed mat alone (over bare soil) or weed mat over compost + sawdust.

Relationships among soil and plant nutrients and yield. Leaf $\mathrm{N}$ concentration, pooled for both cultivars, was positively correlated with yield in 3 of 4 years in flat beds and in 2 years for raised beds (Fig. 5A and B). In our previous study, we reported inconsistent correlations for yield and leaf N, but did find a positive correlation in 'Liberty' for the final 2 years of the study (2015-16, Strik et al., 2019). We did not find correlations within a single cultivar in this study, likely because of the reduced sample size from needing to analyze flat and raised beds separately and with fewer fertilizer treatments for raised beds. An important consideration, however, is that leaf $\mathrm{N}$ increased throughout the study for all prior fertilizer treatments, despite fertilizing with an intermediate $\mathrm{N}$ rate from 2017 through 2020. Based on these results, the increase in yield observed was likely not a result of an increase in average fertilizer rate. While leaf $\mathrm{N}$ was positively correlated with yield in general, leaf $\mathrm{N}$ was higher in 2020 than in 2019 (Figs. 2A and 3A and B), while yield was generally lower in 2020 than in 2019 (Figs. 3 and 4). In 'Duke' during establishment, the combination of weed mat over sawdust increased plant canopy and root volume in young plants compared with weed mat alone (Strik et al., 2020a). We hypothesize that a similar positive response to weed mat over organic mulches occurred in these mature plants, causing an increase in $\mathrm{N}$ uptake (these mulch treatments had the highest leaf $\mathrm{N}$ throughout the study in both bed types) and yield, rather than leaf $\mathrm{N}$ being a causal agent for higher yield.

Previously, we found a negative correlation between leaf $\mathrm{K}$ and leaf $\mathrm{Ca}$ and $\mathrm{Mg}$ concentrations (Strik et al., 2019), whereas this was not found over this 4-year study (data not shown). While leaf $\mathrm{Ca}$ and $\mathrm{Mg}$ were at similar or slightly lower levels in 2020 than in 2016, the lack of correlation suggests that excessive soil $\mathrm{K}$ was no longer limiting uptake of these cations. Despite an overall reduction in leaf K over the course of this study, there was still a negative correlation between yield and leaf $\mathrm{K}$ in 2 of 4 years in flat beds and in all 4 years for raised beds (Fig. 5C and D), as we reported in some years during the prior study, particularly in 'Duke' (Strik et al., 2019). Our results seem to confirm an optimal range in leaf $\mathrm{K}$ of $0.42 \%$ to $0.55 \%$ for maximum yield (Strik et al., 2019). Soil K declined during this study (Fig. 1 ), as no additional sources of $\mathrm{K}$ (from yarddebris compost or from fish solubles fertilizer) were applied since 2016, and leaf $\mathrm{K}$ declined somewhat (particularly in flat beds) but remained within the recommended sufficiency range $(0.41 \%$ to $0.70 \%$; Hart et al., 2006$)$. Although a grower might consider fertilizing with products containing potash to maintain leaf tissue levels, soil $\mathrm{K}$ levels were still above sufficiency (Hart et al., 2006; Horneck et al., 2011), and the persistent negative correlations between leaf $\mathrm{K}$ and yield in this study, particularly in raised beds, which are most common in the industry, suggest this would be a disadvantage for production. We propose lowering the upper end of the leaf sufficiency standards to 

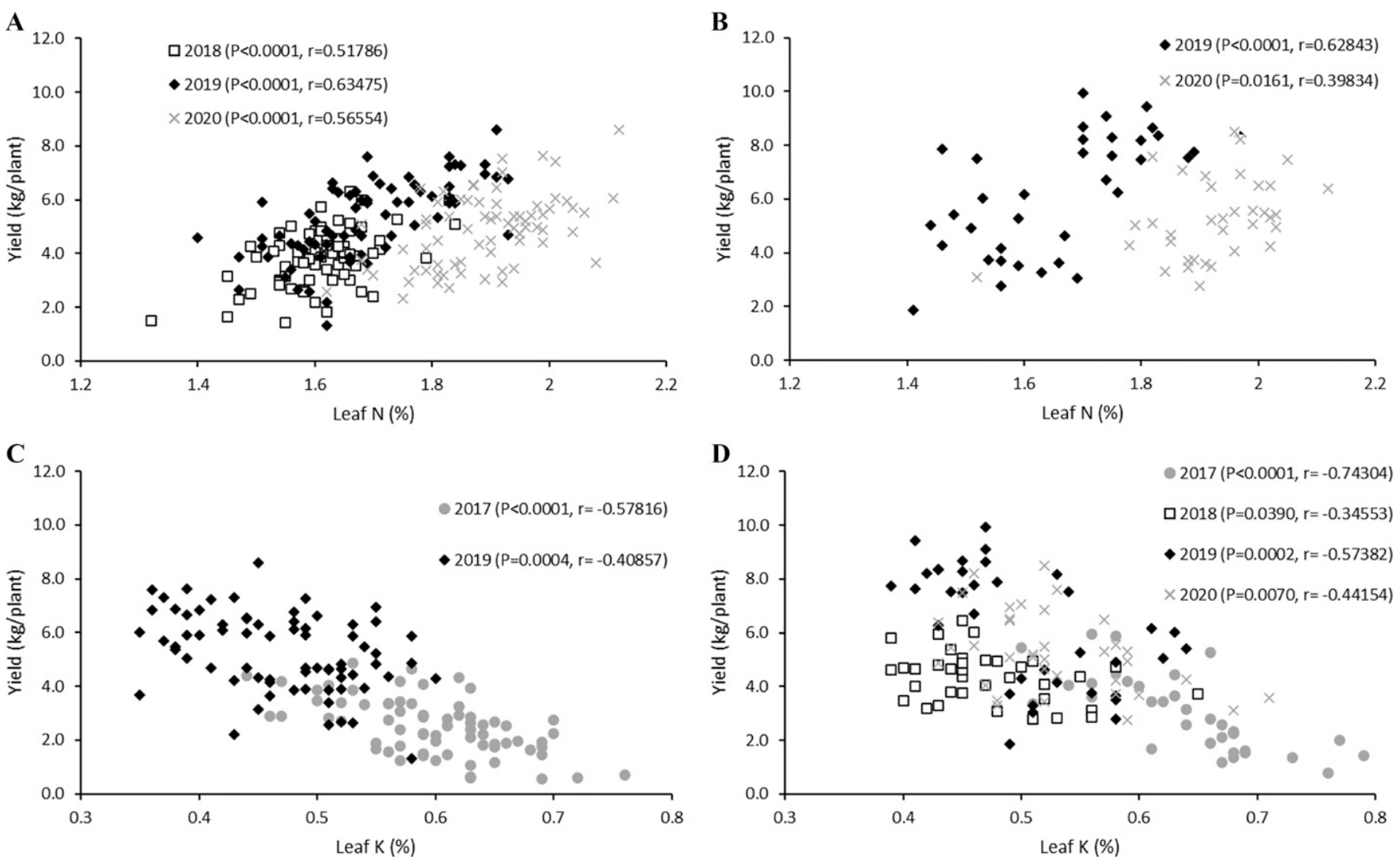

Fig. 5. Relationship between leaf $\mathrm{N}$ concentration and yield for northern highbush blueberry plants grown on flat (A) and raised (B) beds and for leaf $\mathrm{K}$ concentration and yield on flat $(\mathbf{C})$ and raised $(\mathbf{D})$ beds. Each point represents the leaf nutrient concentration and yield in the same year for a plot. Only years with a significant correlation are shown $(P<0.05)$. Actual $P$ values and Pearson's correlation coefficients are given in the legend (n $=72$ for flat beds, and $\mathrm{n}=36$ for raised beds).

$0.55 \%$ leaf $\mathrm{K}$ to discourage application of $\mathrm{K}$ fertilizers when not needed.

\section{Conclusions}

Four years after transitioning mature blueberry plants from their prior mulch and fertilizer treatments, some detrimental effects such as high soil and leaf $\mathrm{K}$ diminished, but other effects were more long-lasting. The use of a plant-based compost mulch increased soil organic matter compared with weed mat alone (Strik et al., 2019). When weed mat was placed over the top of existing sawdust or compost + sawdust mulches, soil organic matter remained higher than for weed mat alone but did not further increase after 4 years, indicating that the mulches did not break down quickly. Even several years after the last compost application, detrimental effects, including high soil $\mathrm{pH}$ and high soil and leaf $\mathrm{K}$, continued to be seen. A good way to increase soil organic matter is to incorporate sawdust at planting (Strik et al., 2020b), but a layer of sawdust under weed mat was found to moderate soil temperature and deter voles (Strik et al., 2020a; Strik and Davis, 2021), maintained soil $\mathrm{pH}$ closer to the desired range, and improved yield even in plants considered mature. Although $\mathrm{pH}$ increased in all treatments from 2016 to 2020 and was above the recommended range, yield also increased, suggesting that there may be other factors, such as soil organic matter, that may help mature plants tolerate a soil $\mathrm{pH}$ above the recommended 5.5.

Fertilizer source and rate, and the resulting impacts on soil and leaf nutrients, had a shorter-term impact than mulch and can be mitigated more quickly and easily by changing fertilizer products. This was particularly true on raised beds where better drainage likely increased leaching of excess nutrients. Soil $\mathrm{K}$ and leaf $\% \mathrm{~K}$ declined after transitioning away from fish solubles and yard-debris compost, leading to fewer negative impacts of soil $\mathrm{K}$ on uptake of $\mathrm{Ca}$ and $\mathrm{Mg}$. Avoiding high $\mathrm{K}$ fertilizers is recommended, unless a deficiency in tissue or soil testing is found. Even when a fertilizer with primarily $\mathrm{N}$ and very low levels of most other nutrients was applied for 4 years, leaf tissue levels were within sufficiency standards, showing the low demand for $\mathrm{K}$ and other nutrients. Yield increased over this study with a moderate $\mathrm{N}$ rate applied, confirming that the higher levels of $\mathrm{N}$ application used previously are not necessarily beneficial. This study has shown that within a relatively short time, some issues like high soil $\mathrm{K}$ and resulting nutrient imbalances can be mitigated and yield increased in plants that were not at optimum productivity.

\section{Literature Cited}

Conant, R.T., M.G. Ryan, G.I. Agren, H.E. Birge, E.A. Davidson, P.E. Eliasson, S.E. Evans, S.D Frey, C.P. Giardina, F.M. Hopkins, R. Hyvonen,
M.U.F. Kirschbaum, J.M. Lavallee, J. Leifeld, W.J. Parton, J.M. Steinweg, M.D. Wallenstein, J.A. Marin Watterstedt, and M.A. Bradford. 2011. Temperature and soil organic matter decomposition rates-synthesis of current knowledge and a way forward. Glob. Change Biol. 17:3392-3404, doi: 10.1111/j.1365-2486.2011.02496.x.

Cox, J. 2009. Comparison of plastic weed mat and woodchip mulch on low chill blueberry soil in New South Wales, Australia. Acta Hort. 810:475482, doi: 10.17660/ActaHortic.2009.810.62.

Davenport, J.R. and L.W. DeVetter. 2019. Evaluating and revising guidelines for blueberry tissue nutrient standards in Washington. Proc. Western Nutrient Management Conf. 13:16-17.

Davidson, E.A., I.A. Janssens, and Y. Luo. 2006. On the variability of respiration in terrestrial ecosystems: Moving beyond $\mathrm{Q}_{10}$. Glob. Change Biol. 12:154-164, doi: $10.1111 / \mathrm{j} .1365-2486.2005$. 01065.x.

DeVetter, L.W., D. Granatstein, E. Kirby, and M. Brady. 2015. Opportunities and challenges of organic highbush blueberry production in Washington State. HortTechnology 25:796-804, doi: 10.21273/HORTTECH.25.6.796.

Fernandez-Salvador, J.A., B.C. Strik, and G.O. Stephenson. 2017. The organic blueberry industry in Oregon: Results of in-person, on-site interviews with growers in 2015. Acta Hort. 1180:409-414, doi: 10.17660/ActaHortic.2017.1180.57.

Hart, J., B. Strik, L. White, and W. Yang. 2006. Nutrient management for blueberries in Oregon. Oregon State University Extension Service. EM 8918. 1 Feb. 2021. <http://ir.library.oregonstate. edu/xmlui/bitstream/handle/1957/20444/em8918. pdf $>$. 
Hart, J.M., D.M. Sullivan, N.P. Anderson, A.G. Hulting, D.A. Horneck, and N.W. Christensen. 2013. Soil acidity in Oregon: Understanding and using concepts for crop production. Oregon State University Extension Service. EM 9061. 10 May 2021. < https://catalog.extension.oregonstate.edu/ em9061>.

Horneck, D.A., D.M. Sullivan, J.S. Owen, and J.M. Hart. 2011. Soil test interpretation guide. Oregon State University Extension Service. EC 1478. 1 Feb. 2021. <https://catalog.extension.oregonstate. edu/sites/catalog/files/project/pdf/ec1478.pdf $>$.

Julian, J.W., B.C. Strik, H.O. Larco, D.R. Bryla, and D.M. Sullivan. 2012. Costs of establishing organic northern highbush blueberry: Impacts of planting method, fertilization, and mulch type. HortScience 47:1-8, doi: 10.21273/HORTSCI.47.7.866.

Karp, K., M. Noormets, M. Starast, and T. Paal. 2006. The influence of mulching on nutrition and yield of 'Northblue' blueberry. Acta Hort. 715:301305, doi: 10.17660/ActaHortic.2006.715.44.

Krewer, G., M. Tertuliano, P. Andersen, O. Liburd, G. Fonsah, H. Serri, and B. Mullinix. 2009. Effect of mulches on the establishment of organically grown blueberries in Georgia. Acta Hort. 810:483-488, doi: 10.17660/ActaHortic.2009. 810.63 .

Larco, H.O. 2010. Effect of planting method, weed management, and fertilizer on plant growth and yield of newly established organic highbush blueberries. Oregon State Univ., Corvallis, MS thesis. 12 Apr. 2019. < http://ir.library.oregon state.edu/xmlui/handle/1957/18065 >.

Larco, H., B.C. Strik, D.R. Bryla, and D.M. Sullivan. 2013a. Weed and fertilizer management practices for organic production of highbush blueberries - I. Early plant growth and biomass allocation. HortScience 48:1250-1261, doi: 10.21273/HORTSCI.48.10.1250.

Larco, H., B.C. Strik, D.R. Bryla, and D.M. Sullivan. $2013 \mathrm{~b}$. Weed and fertilizer management practices for organic production of highbush blueberries-II. Impact on plant and soil nutrients, yield, and fruit quality during establishment. HortScience 48:1484-1495, doi: 10.21273/HORTSCI. 48.12.1484.

Lobos, T.E., J.B. Retamales, A. Luengo Escobar, and E.J. Hansen. 2020. Timing of foliar calcium sprays improves fruit firmness and antioxidants in 'Liberty' blueberry. J. Soil Sci. Plant Nutr. 21:426-436, doi: 10.1007/s42729-020-00371-2.

Magee, J.B. and J.M. Spiers. 1996. Influence of mulching systems on yield and quality of southern highbush blueberries. Journal of Small Fruit \& Viticulture. 3:133-141, doi: 10.1300/J065v03n02_14

Neilsen, G.H., E.J. Houge, T. Forge, and D. Neilsen. 2003. Surface application of mulches and biosolids affect orchard soil properties after 7 years. Can. J. Soil Sci. 83:131-137, doi: 10.4141/S02034.

Sciarappa, W., S. Polavarapu, J. Barry, P. Oudemans, M. Ehlenfeldt, G. Pavlis, D. Polk, and R. Holdcraft. 2008. Developing an organic production system for highbush blueberry. HortScience 43:51-57, doi: 10.21273/HORTSCI.43.1.51.

Strik, B.C. 2014. Organic blueberry production systems - advances in research and industry. Acta Hort. 1017:257-267, doi: 10.17660/ActaHortic. 2014.1017.33.

Strik, B.C. 2016. A review of optimal systems for organic production of blueberry and blackberry for fresh and processed markets in the northwestern United States. Scientia Hort. 208:92-103, doi: 10.1016/j.scienta.2015.11.044.

Strik, B.C. 2020. Pruning blueberry for growth, yield, and quality. Oregon State Univ. Professional and Continuing Ed. online course. $<$ https://workspace. oregonstate.edu/course/pruning-blueberries $>$.

Strik, B.C. and A.J. Davis. 2021. Individual and combined use of sawdust and weed mat mulch in a new planting of northern highbush blueberry. III. Yield, fruit quality, and costs. HortScience 56:363-367, doi: 10.21273/HORTSCI15659-20.

Strik, B.C. and A.J. Vance. 2015. Seasonal variation in leaf nutrient concentration of northern highbush blueberry cultivars grown in conventional and organic production systems. HortScience 50:1453-1466, doi: 10.21273/HORT SCI.50.10.1453.

Strik, B.C. and A. Vance. 2017. Weed management strategies in long-term organic blueberry production systems-Impact of mulch type and weed control methods on economics. Acta Hort. 1180:347-352, doi: 10.17660/ActaHortic.2017. 1180.47 .

Strik, B.C., A. Vance, D.R. Bryla, and D.M. Sullivan. 2017a. Organic production systems in northern highbush blueberry: I. Impact of planting method, cultivar, fertilizer, and mulch on yield and fruit quality from planting through maturity. HortScience 52:1201-1213, doi: 10.21273/HORTSCI12179-17.

Strik, B.C., A.J. Vance, and C.E. Finn. 2017b. Northern highbush blueberry cultivars differed in yield and fruit quality in two organic production systems from planting to maturity. HortScience 52:844-851, doi: 10.21273/HORTSCI11972-17.

Strik, B.C., A. Vance, D.R. Bryla, and D.M. Sullivan. 2019. Organic production systems in northern highbush blueberry: II. Impact of planting method, cultivar, fertilizer, and mulch on leaf and soil nutrient concentrations and relationships with yield from planting through maturity. HortScience 54:1777-1794, doi: 10.21273/ HORTSCI14197-19.

Strik, B.C., A.J. Davis, D.R. Bryla, and S.T. Orr. 2020a. Individual and combined use of sawdust and weed mat mulch in a new planting of northern highbush blueberry I. Impacts on plant growth and soil and canopy temperature. HortScience 55:1280-1287, doi: 10.21273/HORTSCI15122-20.

Strik, B.C., A.J. Davis, and D.R. Bryla. 2020 b. Individual and combined use of sawdust and weed mat mulch in a new planting of northern highbush blueberry II. Nutrient uptake and allocation. HortScience 55:1614-1621, doi: 10.21273/HORTSCI15271-20.

Sullivan, D.M., D.R. Bryla, and R.C. Costello. 2014. Chemical characteristics of custom compost for highbush blueberry, p. 293-311. In: Z. He and H. Zhang (eds.). Applied manure and nutrient chemistry for sustainable agriculture and environment. Springer-Verlag, New York.

Sullivan, D.M., B.C. Strik, and D.R. Bryla. 2015. Evaluation of alternative mulches for blueberry over five production seasons. Acta Hort. 1076: 171-178, doi: 10.17660/ActaHortic.2015.10 76.20 .

Williamson, J., G. Krewer, G. Pavlis, and C.M Mainland. 2006. Blueberry soil management, nutrition and irrigation, p. 60-74. In: N.F. Childers and P.M. Lyrene (eds.). Blueberries for growers, gardeners and promoters. E.O., Gainesville, FL. 